\title{
Correction to: Somatic embryogenesis of a seedless sweet orange (Citrus sinensis (L.) Osbeck)
}

\author{
Jean C. Cardoso ${ }^{1,2} \cdot$ Maisa Curtolo ${ }^{3} \cdot$ Rodrigo R. Latado $^{4} \cdot$ Adriana P. Martinelli $^{2}$
}

Published online: 17 January 2018

(C) The Society for In Vitro Biology 2018

Correction to: In Vitro Cell.Dev.Biol.-Plant (2017)

53:619-623

https://doi.org/10.1007/s11627-017-9866-x

In the original article Fig. 2 was not processed correctly.

Following is the corrected figure:

The online version of the original article can be found at https://doi.org/ 10.1007/s11627-017-9866-x.

Jean C. Cardoso

jeancardosoctv@gmail.com

1 Department of Biotechnology, Plant and Animal Production, Centro de Ciências Agrárias, UFSCar, Rodovia Anhanguera, km 174, CP

153, Araras, SP 13600-970, Brazil

2 Universidade de São Paulo, CENA, Av. Centenário, 303,

Piracicaba, SP 13416-903, Brazil

3 Departamento de Genética, Escola Superior de Agricultura Luiz de Queiroz (ESALQ/USP), Piracicaba, SP, Brazil

4 Centro APTA Citros "Sylvio Moreira"/IAC, Cordeirópolis, SP, Brazil 
Fig. 2 Molecular analysis of Citrus sinensis plants recovered from in vitro ovary cultures. (A) Acclimatized plants obtained from somatic embryos from in vitro culture of ovaries of seedless sweet orange

'Washington Navel'. (B) Flow cytometry analysis of

'Washington Navel' donor plant $(W N)$ and a somatic-embryoderived plant $(S E)$. (C) Target region amplification polymorphism (TRAP) molecular marker profiles of 'Washington Navel' donor plant (control; lane $C)$ and eight somatic-embryoderived plants (lanes 1-8).

Standard base-pair ladder $100 \mathrm{bp}$ to $1000 \mathrm{bp}$ on right
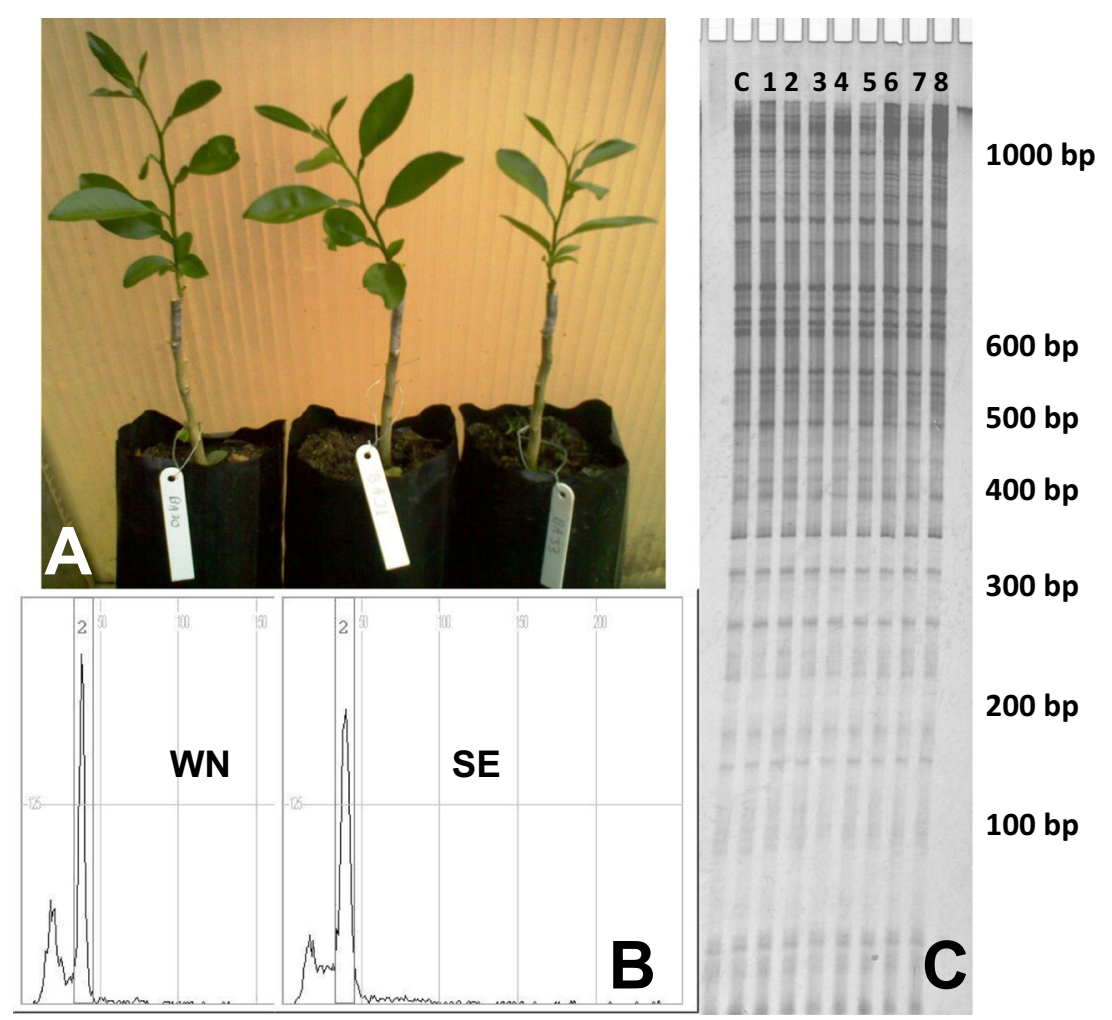

200 bp

100 bp 